\title{
Economics of Fish production and Marketing in Egypt
}

\author{
Yahya M. M. Khalil' ${ }^{1}$, Salah S. Abd El-Ghani ${ }^{2}$, Tamer G. I. Mansour ${ }^{1}$
}

${ }^{1}$ Agricultural Economic Department, 33 El- Buhouth St., Dokki, Giza, Egypt.

1,2 Department of Economics, Faculty of Economics and Administrative sciences- Al Imam Mohammad Ibn Saud Islamic university- Saudi Arabia.

Received: 10 Dec. 2019 / Accepted 10 Jan. 2020 / Publication date: 20 Jan. 2020

\begin{abstract}
The total quantity of fish produced in Egypt is estimated at 1413 thousand tons. The main sources are natural sources such as sea, river Nile and lakes, which produce about 455 thousand tons, and industrial sources such as fish farms, which produce about 957.96 thousand tons, representing $32.2 \%$ and $67.8 \%$, And the amount consumed about 1733 thousand tons and estimated the fish gap is about 290 thousand tons, which are imported from abroad worth about 4131 million pounds for the average period (2010-2018).

Egypt has a problem of low fish production despite the presence of large water bodies in addition to the possibility of increasing industrial sources such as fish farms and fish cages. Fish marketing also faces the greed of intermediaries, with the difficulty of funding for fishermen and weak marketing services.

So come the search goal to identification of the main features of the production of (Tilapia, Mullet, Bayad, Catfish) and how to market fish through the study of producer prices, wholesaler and retailer during the period (1990-1999), (2000-2009), (2010-2018) and the relative distribution of the consumer pound, Monthly seasonal retail prices of varieties during the two periods (2007-2012), (2013-2018).

We conclude from the seasonal study that the fish (Bayad fish and catfish) are good substitutes for mullet, and tilapia and mullet are good substitutes for catfish, and Bayad fish is not a good alternative to tilapia, There is a temporal effect of time on the prices of tilapia, mullet, the positive correlation also shows the months of February, March, June, July and September, which confirms the increased demand for fish in these months, and that the permanent deficit in all sources of protein causes the difficulty of the possibility of substantial decreases in prices during the months of the year. The research recommends attention to the natural resources of fish such as sea, lakes and rivers to increase Egyptian fish production, in addition to increasing fish farms and fish cages, the use of modern technologies in production, the study of problems faced by producers in fish marketing, and the good study of the monthly seasonality of fish production, consumption and prices to bridge the fish gap.
\end{abstract}

Keywords: Economics of fish production, Economics of Fish Marketing, Tilapia, Bayad fish, Mullet, Catfish.

\section{Introduction}

The Arab Republic of Egypt enjoys water bodies and resources for fisheries including ten lakes, including coastal lakes connected to the Mediterranean Sea are Bardawil, Port Fouad, Manzala, Berlus, Edco, Mariout and two lakes passing through the Suez Canal are the lakes Almora and Altmsah and three inland lakes are Qarun and Wadi Rayan and Nasser, Egypt's coast stretches over the Mediterranean and Red Sea for a distance of about $2500 \mathrm{~km}$. Fish production is an important productive activity for food security and economic development in the agricultural sector. It is one of the most important sources of animal protein production with high nutritional value and its price is relatively low compared to other sources for protein.

The total quantity of fish produced in Egypt is estimated at 1413 thousand tons. The main sources are natural sources such as sea, river Nile and lakes, which produce about 455 thousand tons, and industrial sources such as fish farms, which produce about 957.96 thousand tons, representing $32.2 \%$ and $67.8 \%$, And the amount consumed about 1733 thousand tons and estimated the fish gap is

Corresponding Author: Yahya M. M. Khalil, Agricultural Economic Department, 33 El- Buhouth St., Dokki, Giza, Egypt 
about 290 thousand tons, which are imported from abroad worth about 4131 million pounds for the average period (2010-2018).

\section{Research problem:}

Egypt has a problem of low fish production despite the presence of large water bodies in addition to the possibility of increasing industrial sources such as fish farms and fish cages. Fish marketing also faces the greed of intermediaries, with the difficulty of funding for fishermen and weak marketing services.

\section{Search Goal:}

Identification of the main features of the production of (Tilapia, Mullet, Bayad, Catfish) and how to market fish through the study of producer prices, wholesaler and retailer during the period (19901999), (2000-2009), (2010-2018) and the relative distribution of the consumer pound, Monthly seasonal retail prices of varieties during the two periods (2007-2012), (2013-2018).

\section{Research Methodology and Data Sources:}

The study was based on quantitative and descriptive analysis of data such as statistical analysis using simple regression equations by studying the general trend of production, consumption and fish prices for the periods (1990-1999), (2000-2009), (2010-2018) Quantitative analysis methods such as the mathematical model of the seasonality of the monthly retail prices of the studied fish (Tilapia, Mullet, Bayad, Catfish) by multiple regression with the introduction of Dummy variable variables for months $(0,1)$. As for the sources of access to the research data, the secondary data published and unpublished were obtained from several sources such as Central Agency for Public Mobilization and Statistics, Ministry of Agriculture and Land Reclamation represented in the Central Administration of the Agricultural Economy in addition to the General Authority for Fisheries Development.

\section{Results:}

To study the development of Egyptian fish production during the period (1990-2018), it is clear from the first equation that the annual increase is statistically significant, which is about 51.6 thousand tons, representing about $5.6 \%$ of the average estimated at 916 thousand tons, the coefficient of determination is about 0.98 , which means that $98 \%$ of changes in fish production are due to the time factor. In addition, divided the time period into the first three periods (1990-1999). The second equation shows the annual statistical increase of about 30.2 thousand tons representing about $7.9 \%$ of the average estimated at 382.8 thousand tons, the coefficient of determination is about 0.81 .

While the third equation for the period (2000-2009) shows the annual increase of the statistical significance of about 40.7 thousand tons representing about $4.7 \%$ of the average estimated at 862 thousand tons the coefficient of determination is about 0.97 . While the fourth equation for the period (2010-2018) shows the statistically significant annual increase of 38.6 thousand tons representing about $42.7 \%$ of the average estimated at 1413 thousand tons, the coefficient of determination is about 0.98

To study the evolution of fish consumption in Egypt during the period (1990-2018). The first equation shows the annual statistical increase of about 78.6 thousand tons representing about $7.2 \%$ of the average estimated at 1085 thousand tons, the coefficient of determination is about 0.93 , which means that $93 \%$ of changes in fish consumption are due to the time factor. In addition, divided the time period into the first three periods (1990-1999). The second equation shows the statistically significant annual increase of about 58 thousand tons representing about $13.1 \%$ of the average estimated at 443 thousand tons, the coefficient of determination is about 0.89 . While the third equation for the period (2000-2009) shows the annual statistical increase of about 43 thousand tons representing about $4.2 \%$ of the average estimated at 1016 thousand tons, the coefficient of determination is about 0.88 . While the fourth equation for the period (2010-2018) shows the annual increase of the statistical significance of about 165 thousand tons representing about $9.4 \%$ of the average estimated at 1733 thousand tons, the coefficient of determination is about 0.98

Studied the production and consumption of fish at the national level in Egypt during the first period. The annual rate of increase in consumption is about $13.8 \%$ of the estimated average of 443 thousand tons while the annual increase rate of production is about $7.9 \%$ of the average production of 
about 382 thousand tons and the gap is estimated at about 61 thousand tons and the second period (2000-2009), it was found that the average annual increase in consumption is about $4.2 \%$ of the estimated average of 1016 thousand tons, while the annual increase rate of production is about $4.7 \%$ of the average production of about 862 thousand tons and the gap is 206 thousand tons. While the third period (2010 - 2018) showed that, the annual rate of increase of consumption is about $9.4 \%$ of the average estimated at 1733 thousand tons.

Table 1: Equations of the general trend of production and consumption of fish and the gap in Egypt during the period (1990-2018).

\begin{tabular}{ccccccccc}
\hline Item & Time period & $\mathbf{A}$ & $\mathbf{B}$ & $\mathbf{T}$ & $\mathbf{R}^{\mathbf{2}}$ & $\mathbf{F}$ & Average & $\begin{array}{c}\text { Rate of } \\
\text { change\% }\end{array}$ \\
\hline \multirow{3}{*}{ Fish production } & $1990-2018$ & 142 & 51.6 & 3.7 & 0.98 & 1378 & 916 & 5.6 \\
(thousand tons) & $1990-1999$ & 258.9 & 30.2 & 5.9 & 0.81 & 34 & 382.8 & 7.9 \\
& $2000-2009$ & 682 & 40.7 & 18 & 0.97 & 340 & 862 & 4.7 \\
& $2010-2017$ & 1278 & 38.6 & 20.4 & 0.98 & 414 & 1413 & 2.7 \\
Fish consumption & $1990-2018$ & 18.2 & 78.6 & 19 & 0.93 & 358 & 1085 & 7.2 \\
(thousand tons) & $1990-1999$ & 191.7 & 58 & 8.2 & 0.89 & 67.9 & 443 & 13.1 \\
& $2000-2009$ & 962.3 & 43 & 7.6 & 0.88 & 57 & 1016 & 4.2 \\
& $1990-2018$ & 1219 & 165 & 11.3 & 0.94 & 128 & 1733 & 9.4 \\
Fish gap (thousand & $1990-1999$ & 123 & 26.9 & 6.6 & 0.62 & 44.2 & 220.3 & 12.2 \\
tons) & $2000-2009$ & 191.4 & 27.5 & 6.1 & 0.82 & 37 & 61 & 41 \\
& $2010-2018$ & 59 & 126.8 & 7.9 & 0.90 & 62.5 & 377.4 & 33.6 \\
\hline
\end{tabular}

Source:

1- Ministry of Agriculture and Land Reclamation, General Authority for Fisheries Development, Book of Fish Statistics, miscellaneous numbers.

2- Ministry of Agriculture and Land Reclamation, Economic Affairs Sector, Food Balance.

While the uniform rate Annual production Dah about 2.7\% of the average output of about 1413 thousand tons and the gap is estimated at about 377 thousand tons, which confirms that despite the increase in Egyptian fish production. However, the rate of increase in consumption is greater, so production should be increased by optimal utilization of both the coasts, the Nile River and fish farming to reduce the fish gap.

\section{Egyptian Fish Production of Fish Varieties:}

The second part of the study deals with the study of the production of different fish species. The study of the development of Egyptian fish production from tilapia during the period (1990-2018), it is clear from the first equation, that the annual increase is statistically significant and is about 39.2 thousand tons representing about $9.7 \%$ of the average estimated at 405.3 thousand tons, The coefficient of determination is about 0.86 which means that $86 \%$ of changes in tilapia production are due to the time factor.

Dividing the time period into three periods, the first period (1990-1999), It is clear from the second equation that the annual increase is statistically significant and is about 22.9 thousand tons representing about $9.9 \%$ of the average estimated at 131 thousand tons, the coefficient of determination is about 0.89 . While the third equation for the period 2000-2009 shows that the annual increase is statistically significant and is about 20.3 thousand tons representing about $6.6 \%$ of the average estimated 305.3 thousand tons, the coefficient of determination is about 0.77 .

While the fourth equation for the period (2010-2018) shows that the annual increase is statistically significant and is about 79 thousand tons representing about $10.4 \%$ of the average estimated at 760 thousand tons, the coefficient of determination is about 0.85 as shown in Table (2).

While showing the study of the evolution of Egyptian fish production of mullet fish during the period (1990-2018) is evident from the first equation that the annual increase is significant statistically and approximately 7.9 thousand tons, representing about $6.4 \%$ of the average estimated at about this 125.2 thousand tons and has a coefficient of determination around 0.67 , which means $67 \%$ of changes in mullet production are due to time factor, by dividing the time period into three periods, The first period (1990-1999), It is clear from the second equation that the annual increase is statistically 
significant and is about 5.9 thousand tons representing about $23.2 \%$ of the average estimated at 28.1 thousand tons, the coefficient of determination is about 0.79 While the third equation for the period 2000-2009 shows that the annual increase is statistically significant and is about 17.5 thousand tons representing about $11.3 \%$ of the average estimated at 155 thousand tons, and the coefficient of determination is about 0.79 while the fourth equation for the period $2010-2018$ ) showed that the annual increase is statistically significant and is about 10.6 thousand tons representing about $5.9 \%$ of the average estimated at 179 thousand tons, the coefficient of determination is about 0.87

In the study of the development of Egypt's production of Bayad fish during the period (19902018), the first equation shows statistically insignificant. By dividing the time period into three periods, the first period (1990-1999) shows that the annual increase is statistically significant at 0.97 thousand tons, representing about $3.12 \%$ of the average estimated at 6.3 thousand tons, the coefficient of determination is about 0.33 , while the third equation for the period (2000-2009) shows statistically insignificant, while the fourth equation for the period (2010-2018) shows statistically insignificant.

As for the development of Egypt's Catfish production during the period (1990-2018), it is clear from the first equation that the annual increase is statistically significant at 0.822 thousand tons, representing about $2.5 \%$ of the average estimated at 33.4 thousand tons, the coefficient of determination is about 0.31 , which means that $31 \%$ of the changes in Catfish production are due to the time factor. By dividing the time period into three periods, the first period (1990-1999) shows the statistical significance of the second equation, while the third equation for the period 2000-2009 shows that the annual increase is statistically significant at 1.68 thousand tons representing about $4.8 \%$ With an average of about 35 thousand tons, with the coefficient of determination is about 0.79 , while the fourth equation for the period (2010-2018) shows an annual decrease of 3.4 thousand tons, representing about $7.8 \%$ of the average estimated at 44.7 thousand tons, the coefficient of determination is about 0.87 as shown in Table (2).

Table 2: General Time Equations of Production of (Tilapia, Mullet, Bayad, and catfish) in Egypt during the Period (1990-2018).

\begin{tabular}{ccccccccc}
\hline Item & Time period & $\mathbf{A}$ & $\mathbf{B}$ & $\mathbf{T}$ & $\mathbf{R}^{2}$ & $\mathbf{F}$ & $\begin{array}{c}\text { Average } \\
\begin{array}{c}\text { Rate of } \\
\text { change\% }\end{array}\end{array}$ \\
\hline The amount of & $1990-2018$ & 122.6 & 39.2 & 13 & 0.86 & 196.7 & 405.3 & 9.7 \\
Tilapia production & $2000-1999$ & 74.9 & 22.9 & 8 & 0.89 & 64.7 & 131 & 9.9 \\
is 1000 tons & $2010-2017$ & 541 & 79 & 6.2 & 0.85 & 38.9 & 760 & 10.4 \\
\hline The amount of & $1990-2018$ & 12.3 & 7.9 & 7.4 & 0.67 & 55.9 & 125.2 & 6.4 \\
Mullet production & $1990-1999$ & 0.712 & 5.9 & 5.6 & 0.79 & 31.7 & 28.1 & 23.2 \\
is 1,000 tons & $2000-2009$ & 94.2 & 17.5 & 5.8 & 0.81 & 33.4 & 155 & 11.3 \\
\hline The amount of & $1990-2018$ & 122.9 & 10.6 & 6.9 & 0.87 & 47.2 & 179 & 5.9 \\
$\quad 1990-1999$ & 0.981 & 0.57 & 0.528 & 0.01 & 0.28 & 10.02 & 0.56 \\
Bayad fish & $2000-2009$ & 17.8 & 0.532 & 1.2 & 0.17 & 1.7 & 13.6 & 3.12 \\
production is 1000 & $2010-2018$ & 10.8 & -0.573 & 1.4 & 0.19 & 0.22 & 9.5 & 6.1 \\
$\quad$ tons & & & & & & & & \\
\hline The amount of & $1990-2018$ & 20.1 & 0.822 & 3.5 & 0.31 & 12 & 33.4 & 2.5 \\
Catfish production & $2000-1999$ & 17.4 & 0.409 & 1.2 & 0.16 & 1.5 & 18.7 & 2.2 \\
is 1000 tons & $2010-2018$ & 31.5 & 1.68 & 2.2 & 0.38 & 4.96 & 35 & 4.8 \\
\hline Source: & 54.6 & -3.4 & 3.1 & 0.59 & 9.8 & 44.7 & -7.8 \\
\hline
\end{tabular}

Source:

1- Ministry of Agriculture and Land Reclamation، Economic Affairs Sector، Food Balance.

2- According to data from the Central Agency for Public Mobilization and Statistics (CAPMAS) Monthly Bulletin of Food Prices‘ multiple bulletins.

It is clear from the study of fish species that tilapia is the most important species in the production increase during the three study periods and that the third period (2010-2018) is the best period, while the mullet found that the second period (2000-2009) and the third (2010-2018) The most important and most productive periods, And for Bayad fish was found that the first period (19901999) increased the production of Bayad fish, while the increase in production of catfish during the second study period was shown, while the production of catfish decreased during the third period. 


\section{Distribution of consumer pounds:}

It is defined as the distribution of one pounds of the consumer price on the producer, wholesaler and retailer. Table (3) shows the price levels, marketing differences and distribution of consumer pounds for tilapia, mullet, during the three time periods (1990-1999), (2000-), (2018-2010), the table shows that the price of the product, the wholesale price and the retail price for the period (1990-1999) for tilapia amounted to about 5.4, 5.87, 6.2 pounds $/ \mathrm{kg}$, and for the marketing margin it was about 0.8 pounds $/ \mathrm{kg}$ representing about $14.8 \%$ of the product price. The total market value of the product was about 0.47 pounds $/ \mathrm{kg}$ representing about $28.7 \%$ of the marketing margin, and for the distribution of consumer pounds between the producer, the wholesaler and the retailer, their percentage is about $87.1 \%, 7.6 \%$ and $5.3 \%$, respectively.

While the same table is shown the price of the product, the wholesale price and the retail price for the period (2000-2009) for tilapia was about 7.5, 7.99, 9.5 pounds/kg, and for the marketing margin it reached about 2 pounds $/ \mathrm{kg}$, which represents about $26.7 \%$ of the product price .For the product, amounted to about 0.49 pounds $/ \mathrm{kg}$ represents about $26.7 \%$ of the margin of marketing, and for the distribution of consumer pounds between the producer and wholesaler and retailer, the proportion of their respective share of about $78.9 \%, 5.2 \%, 15.9 \%$, respectively.

For the period (2010-2018) it was found that the price of the product and the wholesale price and the retail price of tilapia was about 13.7, 14.8, 19.2 pounds / $\mathrm{kg}$, and for the marketing margin it reached about 5.5 pounds $/ \mathrm{kg}$ representing about $40.1 \%$ of the product price .Total marketing of the product amounted to about 1.1 pounds $/ \mathrm{kg}$ representing about $20 \%$ of the margin of marketing, and for the distribution of consumer pounds between the producer and the wholesaler and retailer, the proportion of their respective share about $71.4 \%, 5.72 \%, 22.9 \%$, respectively.

As for the mullet, it is clear from the table that the price of the product, the wholesale price and the retail price for the period (1990-1999) for mullet reached about 8.9, 9.4, 10.2 pounds $/ \mathrm{kg}$, and for the marketing margin it reached about 1.3 pounds $/ \mathrm{kg}$ representing about $14.6 \%$ It was found that the absolute marketing margin amounted to about 0.5 pounds $/ \mathrm{kg}$ representing about $38.5 \%$ of the marketing margin, and for the distribution of consumer pounds between the producer and the wholesaler and retailer, the percentage of each share is about $87.3 \%, 4.9 \%, 7.8 \%$.Respectively.

While the same table shows that the price of the product, the wholesale price and the retail price for the period (2000-2009) for the mullet was about $12,13,14.3$ pounds $/ \mathrm{kg}$, and for the marketing margin it reached about 2.3 pounds $/ \mathrm{kg}$ representing about $19.2 \%$ of the price of the product ,It was found that the absolute marketing margin of the product amounted to about 1 pounds / $\mathrm{kg}$ representing about $43.5 \%$ of the marketing margin. For the distribution of consumer pounds between the producer and the wholesaler and retailer, the percentage of each share is about $83.9 \%, 6.99 \%$ and $9.1 \%$, respectively.

The third period (2010-2018) shows that the price of the product, the wholesale price and the retail price of mullet was about $27.37,30.3,33.6$ pounds $/ \mathrm{kg}$, and for the marketing margin it reached about 6.23 pounds $/ \mathrm{kg}$, which represents about $23.1 \%$ of the product price .The absolute marketing margin of the product amounted to about 3 pounds / $\mathrm{kg}$ representing about $47.6 \%$ of the margin of marketing, and for the distribution of consumer pounds between the producer and the wholesaler and retailer, the proportion of their respective share about $81.3 \%, 8.9 \%, 9.82 \%$, respectively.

As for the Bayad fish, it is clear from table (3) that the price of the product, the wholesale price and the retail price for the period (1990-1999) for the Bayad fish amounted to about 5.7, 6.23, 7.95 pounds $/ \mathrm{kg}$, and for the marketing margin it was about 2.25 pounds $/ \mathrm{kg}$ representing about 39.5 The absolute marketing margin was about 0.53 pounds $/ \mathrm{kg}$, which represents about $23.6 \%$ of the marketing margin. As for the distribution of consumer pounds between the producer, the wholesaler and the retailer, the proportion of their share is about $71.7 \%, 6.7 \%, 21.6 \%$ respectively.

The price of the product, the wholesale price and the retail price for the period (2000-2009) for the Bayad fish was about 9.4, 9.6, 12.1 pounds $/ \mathrm{kg}$, and for the marketing margin it was about 2.7 pounds $/ \mathrm{kg}$, about $28.7 \%$ It was found that the absolute marketing margin of the product amounted to about 0.2 pounds $/ \mathrm{kg}$ representing about $7.4 \%$ of the marketing margin, and for the distribution of consumer pounds between the producer and the wholesaler and retailer, the proportion of each share is about $77.7 \%, 1.7 \%, 20.7 \%$, respectively. 
Table 3: Price levels, marketing differences and distribution of consumer pounds for Egyptian fish during the period (1990-1999), (2000-2009), (2010-2018).

\begin{tabular}{|c|c|c|c|c|c|c|c|c|c|}
\hline \multirow[t]{2}{*}{ Item } & \multirow[t]{2}{*}{$\begin{array}{l}\text { Time } \\
\text { period }\end{array}$} & \multicolumn{3}{|c|}{ Current prices } & \multicolumn{2}{|c|}{$\begin{array}{l}\text { Marketing } \\
\text { differences }\end{array}$} & \multicolumn{3}{|c|}{$\begin{array}{l}\text { Distribution of consumer } \\
\text { pounds }\end{array}$} \\
\hline & & $\begin{array}{c}\text { Product } \\
\text { price }\end{array}$ & $\begin{array}{c}\text { wholesale } \\
\text { price }\end{array}$ & $\begin{array}{l}\text { retail } \\
\text { price }\end{array}$ & $\begin{array}{c}\text { For } \\
\text { wholesale }\end{array}$ & $\begin{array}{c}\text { For } \\
\text { retailing }\end{array}$ & $\begin{array}{c}\text { Product } \\
\text { share }\end{array}$ & $\begin{array}{c}\text { Wholesale } \\
\text { share }\end{array}$ & $\begin{array}{l}\text { Retai } \\
\text { share }\end{array}$ \\
\hline \multirow[t]{3}{*}{ Tilapia } & $\begin{array}{r}-1990 \\
1999\end{array}$ & 5.4 & 5.87 & 6.2 & 0.47 & 0.33 & 87.10 & 7.58 & 5.32 \\
\hline & $\begin{array}{c}-2000 \\
2009\end{array}$ & 7.5 & 7.99 & 9.5 & 0.49 & 1.51 & 78.95 & 5.16 & 15.89 \\
\hline & $\begin{array}{r}-2010 \\
2018\end{array}$ & 13.7 & 14.8 & 19.2 & 1.1 & 4.4 & 71.35 & 5.73 & 22.92 \\
\hline \multirow[t]{3}{*}{ Mullet } & $\begin{array}{r}-1990 \\
1999\end{array}$ & 8.9 & 9.4 & 10.2 & 0.5 & 0.8 & 87.25 & 4.90 & 7.84 \\
\hline & $\begin{array}{r}-2000 \\
2009\end{array}$ & 12 & 13 & 14.3 & 1 & 1.3 & 83.92 & 6.99 & 9.09 \\
\hline & $\begin{array}{r}-2010 \\
2018\end{array}$ & 27.3 & 30.3 & 33.6 & 3 & 3.3 & 81.25 & 8.93 & 9.82 \\
\hline \multirow[t]{3}{*}{$\begin{array}{l}\text { Bayad } \\
\text { fish }\end{array}$} & $\begin{array}{c}-1990 \\
1999\end{array}$ & 5.7 & 6.23 & 7.95 & 0.53 & 1.72 & 71.70 & 6.67 & 21.64 \\
\hline & $\begin{array}{c}-2000 \\
2009\end{array}$ & 9.4 & 9.6 & 12.1 & 0.2 & 2.5 & 77.69 & 1.65 & 20.66 \\
\hline & $\begin{array}{c}-2010 \\
2018\end{array}$ & 21 & 22.6 & 26.2 & 1.6 & 3.6 & 80.15 & 6.11 & 13.74 \\
\hline \multirow[t]{3}{*}{ Catfish } & $\begin{array}{c}-1990 \\
1999\end{array}$ & 3.4 & 3.6 & 4.85 & 0.2 & 1.25 & 70.10 & 4.12 & 25.77 \\
\hline & $\begin{array}{r}-2000 \\
2009\end{array}$ & 4.8 & 5.38 & 7.12 & 0.58 & 1.74 & 67.42 & 8.15 & 24.44 \\
\hline & $\begin{array}{r}-2010 \\
2018\end{array}$ & 10.1 & 10.5 & 13.4 & 0.4 & 2.9 & 75.37 & 2.99 & 21.64 \\
\hline
\end{tabular}

Source: Calculated from the Central Agency for Public Mobilization and Statistics, Monthly Bulletin of Food Prices (Retail, Wholesale) various publications.

The third period (2010-2018) shows that the price of the product, the wholesale price and the retail price of the Bayad fish amounted to about 21, 22.6, 26.2 pounds / $\mathrm{kg}$, and for the marketing margin it reached about 5.2 pounds / $\mathrm{kg}$ representing about $24.8 \%$ of the product price . That the absolute marketing margin of the product amounted to about 1.6 pounds $/ \mathrm{kg}$ representing about $30.8 \%$ of the margin of marketing, and for the distribution of consumer pounds between the producer and the wholesaler and retailer, the share of each of them about $80.1 \%, 6.1 \%, 13.7 \%$, respectively.

While the same table is shown the total price of the product, the wholesale price and the retail price for the period (1990-1999) for catfish was about 3.4, 3.6, 4.85 pounds / kg. For the marketing margin, it was about 1.45 pounds $/ \mathrm{kg}$, which represents about $42.6 \%$ of the price of the product . Amounted to about 0.2 pounds $/ \mathrm{kg}$ representing about $13.8 \%$ of the margin of marketing, and for the distribution of consumer pounds between the producer and wholesaler and retailer, the proportion of their respective share about $70.1 \%, 4.12 \%, 25.8 \%$, respectively.

It is clear from the same table that the price of the product, the wholesale price and the retail price for the period (2000-2009) for catfish was about 4.8, 5.36, 7.12 pounds $/ \mathrm{kg}$, and for the marketing margin it was about 2.32 pounds $/ \mathrm{kg}$, which represents about $48.3 \%$ of the product price . The absolute marketing margin of the product amounted to about 0.58 pounds $/ \mathrm{kg}$ representing about $25.5 \%$ of the marketing margin. As for the distribution of consumer pounds between the producer, the wholesaler and the retailer, the percentage of their share is about $67.4 \%, 8.1 \%$ and $24.4 \%$, respectively.

The third period (2010-2018) shows that the price of the product, the wholesale price and the retail price of the catfish was about 10.1, 10.5, 13.4 pounds $/ \mathrm{kg}$, and for the marketing margin it reached about 3.3 pounds $/ \mathrm{kg}$ representing about $32.7 \%$ of the product price .The absolute marketing margin of the product reached about 0.4 pounds $/ \mathrm{kg}$ representing about $12.1 \%$ of the marketing 
margin. Regarding the distribution of consumer pounds between the producer, the wholesaler and the retailer, the percentage of their share is about $75.4 \%, 2.99 \%$ and $21.6 \%$, respectively.

The study of the distribution of consumer pounds revealed that the third time period (2010-2018) is the lowest period of the share of the product from the consumer pounds of tilapia, which reached $71.35 \%$ against the increase of the share of the retailer from consumer pounds, which reached about $22.92 \%$ this is also confirmed for mullet, as for the distribution of the consumer's pounds to the Bayad fish, it was found that the first period Where the share of the product is low was about $71.7 \%$, while the share of the product of catfish was $67.4 \%$ for the second period, which confirms the monopoly and greed of retailers and wholesale consumers.

\section{Monthly seasonal effect of retail prices of fish species :}

To measure the seasonal changes in prices of Egyptian fish production of the types selected by the study either for the availability of data or for the high consumption of others. The multiple regression model was also used using visual variables to express the monthly seasonal effect, and visual variables the regression models are often interpreted as explanatory or explanatory variables to express descriptive variables or how they express distinct features, and are entered in the form with special specifications, they take the correct one if the existence of the attribute and take zero if not exist such as monthly seasonal.

Table (4) shows the relationship between the prices of one of the varieties (tilapia, Mullet, Bayad fish, catfish) and other varieties, and by estimating the relationship between the price of tilapia as a dependent variable and the monthly price for mullet, Bayad and catfish, as independent variables it was found that $88 \%$ of the changes in the monthly prices of tilapia were due to the monthly changes in prices of the other items studied in addition to the time variable and the seasonal effect of the months. As estimated by prices there was an inverse relationship between the price of Bayad fish and the price of tilapia per month, as a change in the monthly price of Bayad fish was 1 pound $/ \mathrm{kg}$ followed by a change in the tilapia rate of 0.276 pounds $/ \mathrm{kg}$. The significance of this relationship was statistically significant at 0.01 level. Is not an alternative to tilapia, and the statistical significance of time and month of July was confirmed, while the statistical significance of the remaining variables was not confirmed.

As for the relationship between the monthly price of mullet and the prices of other varieties, it was estimated that $96 \%$ of the changes in monthly prices of mullet are due to monthly changes in prices of other items studied in addition to the time variable and the seasonal effect of months, as showed the equation for the prices of mullet fish to there is a direct relationship between the price of the thickness of the white and the calves and the price of tilapia as change in the monthly price of Bayad fish and catfish is estimated in pounds $/ \mathrm{kg}$, followed by a change in a positive relationship in the price of tilapia of $0.303,1.2$ pounds $/ \mathrm{kg}$, and this relationship was statistically significant at a significant level of 0.01 , which confirms that the Bayad fish and catfish are good alternatives to mullet and confirmed the statistical significance of the time variable and the month of January, While the statistical significance of the remaining variables was not confirmed.

While the same table is shown the relationship between the monthly price of the Bayad fish and the monthly prices of the other varieties is statistically uncertain and that the time component was statistically significant at a significant level of 0.05 while the statistical significance of June and September was confirmed and the significance of this relationship was statistically significant at 0.01 While the statistical significance of the remaining variables was not confirmed, the coefficient of determination was 0.91 , the form was confirmed (F) calculated at 38.7 which confirms the significance of the model used.

And the study of the relationship between the monthly price of catfish and other types of prices, it was estimated that $77 \%$ of the changes in the monthly prices of catfish are due to the monthly changes in the prices of the other items studied the statistical significance of the time variable and the seasonal effect of months were not confirmed, Price estimates have shown a positive correlation between the price of tilapia and mullet and the monthly price of fish, a change in the monthly price of tilapia and mullet is one pound/ $\mathrm{kg}$, Followed by a positive relationship, for catfish price of 0.095 , 0.398 pounds $/ \mathrm{kg}$. This correlation was statistically significant at 0.01 level, confirming that tilapia and mullet were good substitutes for catfish, and statistical significance was confirmed for March, while the statistical significance of the remaining variables was not confirmed. 
Table 4: Results of the Statistical Estimation of the Monthly Seasonal Effects of the Prices of tilapia, mullet and whites, and catfish for the period (2013-2018)

\begin{tabular}{lcccc}
\hline Parametric & Tilapia fish & Mullet fish & Bayad fish & Catfish \\
\hline a0 & -1.62777 & 10.29965 & 8.659448 & -2.75368 \\
a1 & $* * .248837$ & $* * 0.154324$ & $* 0.09083$ & -0.11361 \\
P1 my & - & 0.049646 & -0.12088 & $* * 0.095238$ \\
P2 my & 0.229857 & - & 0.616045 & $* * 0.398226$ \\
P3 my & $* *-0.27554$ & $* * 0.303306$ & - & -0.00503 \\
P4 my & 1.3304050 & $* * 1.201513$ & -0.03082 & - \\
D1 & 0.801991 & -1.11426 & 0.895725 & 0.511922 \\
D 2 & 0.649872 & $* 1.24251$ & 0.625793 & 0.633237 \\
D 3 & 0.466112 & -0.24535 & -0.25334 & $* * 0.336672$ \\
D 4 & 1.70676 & 0.967712 & -0.3159 & -0.31208 \\
D 5 & 0.261703 & 0.612828 & -0.63091 & 0.043834 \\
D 6 & -0.42952 & 0.977388 & $* *-3.28795$ & 0.093537 \\
D 7 & $* * .426036$ & 0.778097 & -1.00896 & -0.69418 \\
D 8/ & -0.36973 & -0.27919 & -0.65316 & 0.425456 \\
D 9 & -0.22965 & 0.087389 & $* *-0.63913$ & 0.10015 \\
D 10 & -0.5699 & -0.11083 & -1.35593 & 0.260702 \\
D 110 & -0.50371 & 0.291352 & -2.24079 & 0.090589 \\
R2 & 0.88 & 0.96 & 0.91 & 0.77 \\
F & 27.8 & 104.4 & 38.7 & 12.6 \\
\hline
\end{tabular}

Whereas:

*Significant level $0.05 * *$ Significant level 0.01

Source: Central Agency for Public Mobilization and Statistics, Monthly Bulletin of Retail Prices, Various bulletins.

We conclude from the seasonal study that the fish (Bayad fish and catfish) are good substitutes for mullet, and tilapia and mullet are good substitutes for catfish, and Bayad fish is not a good alternative to tilapia, There is a temporal effect of time on the prices of tilapia, mullet, the positive correlation also shows the months of February, March, June, July and September, which confirms the increased demand for fish in these months, and that the permanent deficit in all sources of protein causes the difficulty of the possibility of substantial decreases in prices during the months of the year. The research recommends attention to the natural resources of fish such as sea, lakes and rivers to increase Egyptian fish production, in addition to increasing fish farms and fish cages, the use of modern technologies in production, the study of problems faced by producers in fish marketing, and the good study of the monthly seasonality of fish production, consumption and prices to bridge the fish gap.

The following statistical model was formulated to reflect the relationship between the price of each selected fish species and the rest of the varieties during the period (2013-2018). The price relations will be measured through that model for each category of selected varieties. The price of the item is considered a dependent variable and the prices of the other items are independent variables. The model formulas take the following form:

$\mathrm{P}_{\mathrm{my}}=\mathrm{a}_{0}+\mathrm{a}_{1} \mathrm{~T}_{\mathrm{ym}}+\mathrm{b}_{\mathrm{i}} \mathrm{D}_{\mathrm{my}}+\mathbf{C}_{1} \mathrm{P}_{1 \mathrm{my}}+\mathbf{C}_{2} \mathrm{P}_{2 \mathrm{my}}+\mathbf{C}_{3} \mathrm{P}_{3 \mathrm{my}}+\mathbf{C}_{4} \mathrm{P}_{4 \mathrm{my}}+\mathbf{C}_{5} \mathrm{P}_{5 \mathrm{my}}+\mathbf{C}_{6} \mathrm{P}_{6 \mathrm{my}}+\mathrm{E}_{\mathrm{my}}$ Whereas:

P my: Average monthly price of the fish species taken into account for the market during the month $\mathrm{m}$ for the period (2018-2013).

T ym: A value that expresses the time variable in a monthly picture during the period considered.

D my: A transitional variable that reflects the seasonal months from January to November.

m: Indicates the variable of the transition variable and takes the values from (11-1).

y: refers to months and equal (12-1) during the period (2018-2013).

P1 my: monthly average price of Tilapia during the period considered.

P2 my: The monthly average price of Mullet during the period considered.

P3 my: monthly average price of Bayad fish during the period considered.

P4 my: The monthly average of the price of Catfish during the period considered.

a0, a1, c: Time, intersection and price parameters.

E my: A random variable that expresses error and irregularity. 
It should be noted that in this model, the seasonal variable for the seasonal effect of December was excluded at the monthly estimate of the function in order to avoid falling into the trap of transition variables.

\section{References}

Al-Saeed Abdel-Hamid Al-Bassiouni, et al., "Economic Analytical Study of Production and Consumption of Fish in Egypt," Egyptian Journal of Agricultural Economics, Vol. 13, No. 3, September 2003.

Central Agency for Public Mobilization and Statistics, Statistical Yearbook.

Guajarati, D., 1978.Basic Econometrics, McGraw Hill Kogakusha, Ltd. Tokyo.

Hanaa Shadad Mohamed Abdel Latif, 2009. Economic Study of Fish Production in Egypt, Egyptian Journal of Agricultural Economics, Vol. 19, No. 4, December 2009.

Ministry of Agriculture and Land Reclamation, Economic Affairs Sector, Agricultural Economics Bulletin, miscellaneous numbers.

Ministry of Agriculture and Land Reclamation, Economic Affairs Sector, Bulletin of prices of animal products, poultry and fish, miscellaneous numbers.

Ministry of Agriculture and Land Reclamation, Economic Affairs Sector, Food Balance.

Mohamed El Sayed Hussein Laby, 2017 Marketing Efficiency of Some Egyptian Fish Varieties, Egyptian Journal of Agricultural Economics, Vol. 27, No. 2, June (b), 2017.

Mohamed Sobhi Ibrahim Fayed, 2014. Economics of Fish Production and Marketing in Egypt, PhD Thesis, Department of Agricultural Economics, Faculty of Agriculture, Ain Shams University, 2014.

Shahira Mohammad Rida Ibrahim Attia, 2006. Economics of Fish Production and Marketing in Egypt, Master Thesis, Faculty of Agriculture, Ain Shams University, 2006.

The Central Agency for Public Mobilization and Statistics (CAPMAS), Annual Bulletin of Prices of Food Products and Services (Producer / Wholesale / Consumer), Miscellaneous Numbers. 